\title{
Reconstructing glacier-based climates of LGM Europe and Russia - Part 2: A dataset of LGM precipitation/temperature relations derived from degree-day modelling of palaeo glaciers
}

\author{
R. Allen ${ }^{1, *}$, M. J. Siegert ${ }^{2}$, and A. J. Payne ${ }^{1}$ \\ ${ }^{1}$ School of Geographical Sciences, University of Bristol, University Road, Bristol, BS8 1SS, UK \\ ${ }^{2}$ School of GeoSciences, University of Edinburgh, Grant Institute, King's Buildings, West Mains Road, \\ Edinburgh, EH9 3JW, UK \\ *now at: Landmark Information Group, 5-7 Abbey Court, Eagle Way, Sowton, Exeter, EX2 7HY, UK
}

Received: 26 September 2007 - Published in Clim. Past Discuss.: 26 October 2007

Revised: 16 September 2008 - Accepted: 22 September 2008 - Published: 13 November 2008

\begin{abstract}
The study of European and Russian Quaternary glacial-geological evidence during the last 15 years has generated sufficient data to use former glacial extent as a proxy for Last Glacial Maximum (LGM) climate (precipitation and temperature) at a continental scale. Utilisation of such data is relevant for two reasons. First, continental to global scale proxy reconstructions of past climate are an important tool in the assessment of retrospective general circulation model (GCM) simulations. Second, the development of a multiproxy approach will result in a more robust proxy based climate signal. A new and independent dataset of 36 LGM precipitation and temperature relationships derived from European and Russian mountain regions is presented in this paper. A simple glacier-climate model was used to establish the optimum LGM precipitation/temperature conditions for each region from a suite of over 4000 model climates using the principle of zero cumulative mass balance. Clear regional trends are present in the reconstructed LGM precipitation and temperature curves; assuming present precipitation temperature anomalies north of the Alps are $2^{\circ} \mathrm{C}$ and $5^{\circ} \mathrm{C}$ larger than those in the western and eastern Mediterranean, respectively. In Russia the model results suggest that the climates in both the Arctic Urals and Puterana Plateau were probably conducive to the existence of small mountain glaciers at the LGM.
\end{abstract}

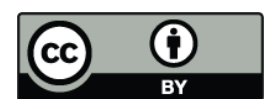

Correspondence to: $\mathrm{M}$. Siegert

(m.j.siegert@ed.ac.uk)

\section{Introduction}

The Last Glacial Maximum (LGM) $\left(\sim 18000^{14} \mathrm{C}\right.$ yr BP) is the most recent prolonged cold phase in the Earth's history, yet terrestrial proxy evidence suggests significant regional variation in the degree of climate change during this time period. European temperature anomalies (the difference between the temperature today and at the LGM), reconstructed from fossil pollen, range from $-17^{\circ} \mathrm{C}$ in Central Europe to $-1^{\circ} \mathrm{C}$ in Arctic Russia (Peyron et al., 1998; Tarasov et al., 1999; Wu et al., 2007; Ramstein et al., 2007). Glacial-geological evidence in Northern Hemisphere midlatitude mountainous regions suggests the advance of mountain glaciers was restricted during the LGM (e.g. Herail et al., 1986; Ono et al., 2005; Owen and Benn, 2005); potentially reflecting a state of precipitation starvation (Gillespie and Molnar, 1995). In the tropics, LGM temperature anomalies, reconstructed from fossil pollen at low elevation, range between $-2.5^{\circ} \mathrm{C}$ and $-3^{\circ} \mathrm{C}$ (Farrera et al., 1999). In contrast, temperature anomalies from tropical LGM glaciers range from $-6^{\circ} \mathrm{C}$ to $-12^{\circ} \mathrm{C}$ (Mark et al., 2005). Steeper altitudinal lapse rates during the LGM may explain the differences between these anomalies (Farrera et al., 1999; Kageyama et al., 2005).

Regional trends in palaeoclimate, or palaeoenvironment, reconstructed from terrestrial proxy data have been used to assess General Circulation Model (GCM) simulations of the LGM (e.g. the Palaeoclimate Modelling Intercomparison Project (PMIP) (Joussame and Taylor, 1995) and PMIP2 collaborative projects, Harrison et al., 2002; Braconnot et al., 2007). It is important to continue developing regional scale proxy palaeo-information because it can be used to test the

Published by Copernicus Publications on behalf of the European Geosciences Union. 


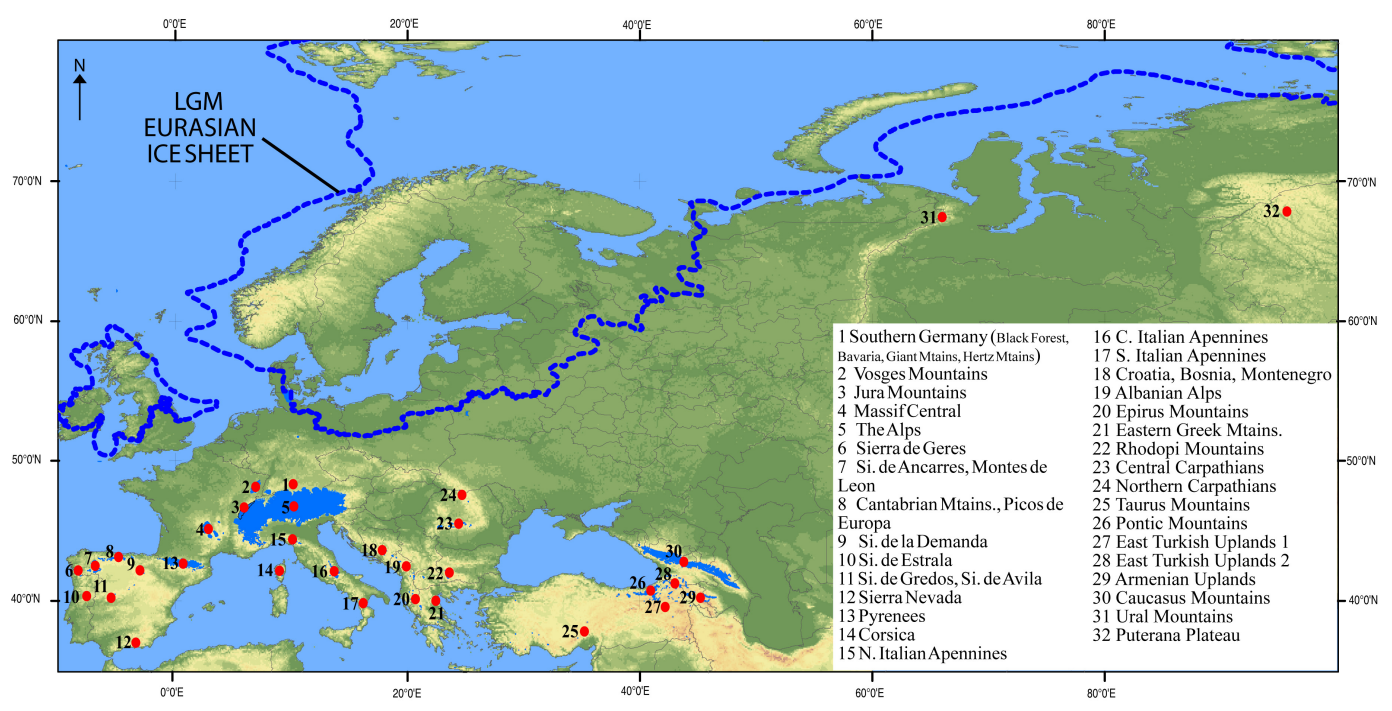

Fig. 1. Location of Quaternary glacial-geological evidence in Europe and Russia (adapted from Ehlers and Gibbard, 2004a).

reliability of trends present in individual data sources; such analyses will increase the confidence in subsequent GCM comparisons. The LGM climate of Europe is in particular need of such analysis as there is currently only one quantitative continental-scale dataset of the LGM climate, derived from proxy evidence (Peyron et al., 1998; Tarasov et al., 1999). The publication of a global dataset of Quaternary glaciers (Ehlers and Gibbard, 2004a-c) has made it possible to use glacial-geological evidence to construct independent quantitative LGM climate reconstructions at the continental scale. This paper presents precipitation/temperatue reconstructions from glacier-climate model simulations of LGM glaciers in mid-latitude Europe and Arctic Russia, using the numerical technique outlined in Allen et al. (2007a, b). A glossary of all acronyms used in this paper can be found in Appendix A.

\section{The structure of proxy palaeoclimate datasets}

To maximise the potential of proxy evidence, especially when intended for use in data-model comparison projects, it is important to consider the methodology used and the final structure of the palaeo-dataset. It has been suggested that proxy palaeo-datasets should have the following six characteristics: First, a continental to global coverage. The resolution of many GCMs equates to a grid box width of between $300-50 \mathrm{~km}$ (Jost et al., 2005); as a result they cannot (yet) be expected to resolve local scale phenomena that would influence, and be recorded by, individual terrestrial proxy sites. Continental scale coverage enables many individual proxy sites to be used to test regional trends that are resolved in GCM simulations (Kohfeld and Harrison, 2000). Second, compatibility with model output; the data should be directly compatible with model output and ideally be accompanied by an indication of uncertainty in the results (Kohfeld and Harrison, 2000; Harrison, 2003). Third, transparent primary data which allows the location of data points and original observation to be identified and viewed (Harrison, 2003). Fourth, detailed documentation describing assumptions, data transformations, and methods used. This should allow the dataset to be assessed by users and ensure that the work is replicable. Also, it will enable re-evaluation of the dataset as reconstructive techniques and mechanistic understandings improve (Harrison, 2003). Fifth, provision of metadata (e.g. site details or chronological framework), allowing users to sub-sample appropriate data for specific tasks (Kohfeld and Harrison, 2000; Harrison, 2003). Sixth, results presented in a site by site format (e.g. Farerra et al., 1999; Kohfeld and Harrison, 2000; Tarasov et al, 2000; Bigelow et al., 2003). This approach removes the possibility of erroneous interpolations, makes the data more accessible, and should enable a more reliable model-data comparison. A traditional method of presenting proxy based reconstructions has been through maps (e.g. CLIMAP Project Members, 1981; Denton and Hughes, 1981), which rely on the interpretation of the available data by the map maker. This approach has two weaknesses, first, the accessibility of the data to the wider academic community is reduced because a knowledge of the maps background and justification for the interpolations is required and, second, the potential for errors in the data set is increased (Harrison, 2003).

The dataset of LGM climate reconstructions derived from the glacial-geological evidence of Europe presented in the remainder of this paper has been designed, as far as is possible, to include these criteria to ensure that the results can be utilised to their maximum potential. 
Table 1. Number of reconstructed glacier profiles, and total glaciated area in each region used to reconstruct LGM climate estimates.

\begin{tabular}{lrr}
\hline Region & Number of model sites & Regional glaciated area $\left(\mathrm{km}^{2}\right)$ \\
\hline Sierra de Gerês (Portugal) & 3 & 52 \\
Sierra des Ancarres and Montes de León (Spain) & 6 & 782 \\
Cantabrian Mountains and Picos de Europa (Spain) & 20 & 574 \\
Pyrenees (France and Spain) & 6 & 11832 \\
Sierra de la Demanda (Spain) & 3 & 36 \\
Sierra de Gredos and Sierra de Ávila (Spain) & 3 & 126 \\
Sierra de Estrala (Portugal) & 1 & 72 \\
Sierra Nevada (Spain) & 1 & 54 \\
Black Forest (Germany) & 1 & 701 \\
Vosges (France) & 4 & 1515 \\
Massif Central (France) & 6 & 4745 \\
Jura Mountains (France and Switzerland) & 1 & 4367 \\
Corsica (France) & 4 & 346 \\
N. Italian Apennines (Italy) & 9 & 299 \\
C. Italian Apennines (Italy) & 13 & 501 \\
S. Italian Apennines (Italy) & 2 & 26 \\
Bosnian and Montenegrian Mountains & 3 & 337 \\
Albanian Alps & 6 & 906 \\
Epirus Mountains (Greece) & 9 & 427 \\
Mt Olympus and Mt. Parnnasos (Greece) & 2 & 106 \\
Rhodopi Mountains (Bulgaria) & 2 & 850 \\
Central Carpathians (Romania) & 11 & 914 \\
Northern Carpathians (Romania) & 3 & 193 \\
Pontic Mountains (Turkey) & 8 & 3498 \\
Central Turkish Uplands & 7 & 174 \\
Eastern Turkish Uplands & 18 & 879 \\
Armenian Uplands & 11 & 1523 \\
Western Caucasus (Georgia and Russia) & 10 & 14434 \\
Eastern Caucasus (Georgia, Azerbaijan, and Russia) & 6 & 12319 \\
\hline
\end{tabular}

\section{The Last Glacial Maximum cryosphere of Europe and Russia}

The Eurasian Ice Sheet dominated the northern latitudes of Europe at the LGM (Hubberten et al., 2004). Beyond the southern margins of the ice sheet many of the mountain ranges in mid-latitude Europe contain glacial-geological evidence which has been attributed to the LGM (Fig. 1), and used to describe a wide range of glacial systems, the largest of which was the Alpine ice cap (e.g. Florineth and Schlüchter, 2000). The orographies of the Pyrenees and Caucasus Mountains enabled significant mountain glacier systems, drained by outlet glaciers up to $70 \mathrm{~km}$ in length to develop (Calvet, 2004; Gobejishvili, 2004). To the north and west of the Alps small ice caps (up to $500 \mathrm{~km}^{2}$ ) developed in the Vosges Mountains, Jura Mountains, and Massif Central (Dricot et al., 1991; Gillespie and Molnar, 1995; Buoncristiani and Campy, 2001). Evidence of Quaternary cirque and mountain glaciers can be found in upland regions across the Mediterranean Basin and Turkey as far south as $35^{\circ} \mathrm{N}$ (Fig. 1) (see Ehlers and Gibbard (2004a) and references therein for a full review).
The position of the eastern margin of the Eurasian Ice Sheet has been established by Svendsen et al. (2004). They indicate the ice sheet was restricted to the present day coastal regions of northern Russian and Siberia, leaving self sourced ice masses in the upland regions of the Ural Mountains and Puterana Plateau (Fig. 1) (e.g. Boulton, 1979; Hubberten et al., 2004). Recent modelling work supports the interpretation that the Eurasian Ice Sheet had retreated from Arctic Russia by the LGM, owing to an extremely cold and dry climate (Siegert and Marsiat, 2001). Assuming that this interpretation is correct, small cirque and valley glaciers would have formed in the Ural Mountains during the LGM (Astakhov, 1997; Svendsen et al., 2004; Hubberten et al., 2004), however the exact number and extent of these glaciers remains unknown. The chronology of the Late-Quaternary glaciers in the Puterana Plateau is still debated: Astakhov (2004) suggests that a large ice cap covered the region during the LGM; Svendsen et al. (2004) date this ice cap to between 60 and 50 ka BP, and suggest that by the LGM only the upper reaches of the Puterana Plateau were glaciated. 


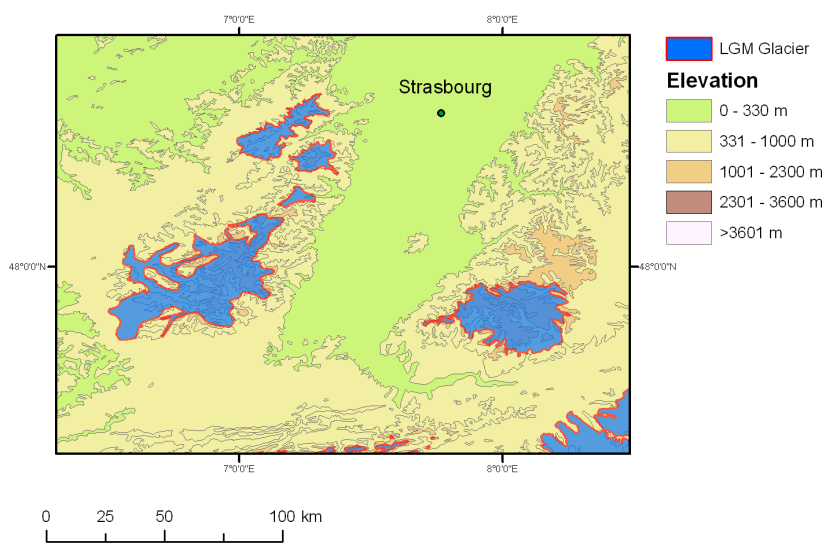

Fig. 2. Extract from Plate NK21 of the INQUA GIS of Quaternary glaciers, covering the Vosges Mountains, France (and Black Forest Mountains, Germany). Figure adapted from Ehlers and Gibbard (2004a).

\section{Regional glacier-climate simulations of the Last Glacial Maximum}

\subsection{The INQUA dataset of Quaternary glaciers}

In 1995 the XIV Congress of the International Quaternary Association (INQUA) commissioned a project to establish a comprehensive dataset of the global extent and chronology of Quaternary glaciations. The European and Russian section of this project was published in 2004 (Ehlers and Gibbard, 2004a) and represents the culmination of work from numerous authors across many different countries and is, to date, the most comprehensive dataset of Quaternary glaciers (including the LGM) in Europe and Russia. The data contributing to this publication are contained in an accompanying ArcView GIS (Fig. 2).

The LGM glacier reconstructions required to constrain glacier-climate model (Allen et al., 2007a) simulations of LGM climate were constructed by overlaying the INQUA GIS dataset on top of the USGS "gtopo30 arcsec" DEM (USGS, 1996). Using this combined approach to reconstruct LGM glacier topography yielded 182 discrete LGM glacier profiles from 29 mountainous regions across Western Europe and Black Sea region. Results from individual glaciers within each mountain region were combined to produce a regional climate reconstruction (Table 1). Results from individual sites within the same region were combined using a weighting system reflecting the relative glaciated area of the different contributing glaciers. This regionalisation meant that the number of contributing simulations or simulated glacier area was not uniform between regions, and it had to be assumed that results derived from regions with small LGM glaciers are equally as valid as those derived from the more heavily glaciated regions.
Table 2. Details of model LGM mountain glaciers in the Arctic Urals and Puterana Plateau used to reconstruct potential LGM climates. The size and ELA range span the minimum and maximum LGM glaciers described in the literature. The glacier profiles were derived by assuming that the accumulation area occupied the highest altitude DEM cells in each model domain.

\begin{tabular}{lrrrrr}
\hline & \multicolumn{5}{c}{ Accumulation Area Size $\left(\mathrm{km}^{2}\right)$} \\
\hline Region & $0 \%$ & $1 \%$ & $2 \%$ & $4 \%$ & $6 \%$ \\
\hline Arctic Urals 1 & & 44 & 88 & 172 & 257 \\
Arctic Urals 2 & & 20 & 39 & 77 & 115 \\
Central Urals 1 & & 111 & 220 & 446 & 676 \\
Central Urals 2 & & 60 & 125 & 245 & 373 \\
Central Urals 3 & & 97 & 191 & 394 & 586 \\
Southern Urals & & 322 & 638 & 1279 & 1967 \\
Puterana Plateau & & 1471 & 2973 & 5940 & 11158 \\
\hline \multicolumn{1}{c}{ Equilibrium Line Altitude } & $(\mathrm{m})$ & & \\
\hline Arctic Urals 1 & 1232 & 1080 & 1035 & 965 & 920 \\
Arctic Urals 2 & 1366 & 1106 & 1051 & 991 & 946 \\
Central Urals 1 & 1775 & 1345 & 1275 & 1200 & 1150 \\
Central Urals 2 & 1400 & 1056 & 981 & 921 & 881 \\
Central Urals 3 & 1516 & 1091 & 986 & 891 & 846 \\
Southern Urals & 1603 & 1073 & 998 & 918 & 868 \\
Puterana Plateau & 1646 & 1381 & 1326 & 1251 & 1166 \\
\hline
\end{tabular}

As discussed in Sect. 3 the extent of LGM glaciers in the Ural Mountains and Puterana Plateau is currently uncertain. The INQUA LGM glacier dataset (Ehlers and Gibbard, 2004a) contains no data describing LGM glaciers in the Ural Mountains, and describes the large ice cap $\left(\sim 162000 \mathrm{~km}^{2}\right)$ in the Puterana Plateau reconstructed by Astakhov (2004). The alternative interpretations of LGM glaciers in these two regions provide starkly contrasting maxima and minima that must reflect significantly different overlying palaeoclimatic conditions. This uncertainty was incorporated into the LGM palaeoclimate dataset by creating mountain glaciers which occupied the upland reaches of each region (Table 2). This method of representing small mountain glaciers was used in both regions alongside the LGM glacier profiles described in the INQUA dataset (Ehlers and Gibbard, 2004a) (Table 2). The Puterana Plateau was modelled as a single region and, owing to its length, the Ural Mountains was divided into six regions (Arctic Urals $1,69^{\circ} \mathrm{N}-67^{\circ} \mathrm{N}$, Arctic Urals 2, $67^{\circ} \mathrm{N}-$ $66^{\circ} \mathrm{N}$, Central Urals $1,66^{\circ} \mathrm{N}-64^{\circ} \mathrm{N}$, Central Urals $2,64^{\circ} \mathrm{N}-$ $61^{\circ} \mathrm{N}$, Central Urals $3,61^{\circ} \mathrm{N}-58^{\circ} \mathrm{N}$, and Southern Urals 1 , $56^{\circ} \mathrm{N}-51^{\circ} \mathrm{N}$ (see Fig. 6.1 in Allen, 2006).

The model assumes that the glacier extents in Ehlers and Gibbard (2004) are correct and that their extents were reached at the same time. We acknowledge that neither assumptions are likely to be strictly true, however (for further details see Sect. 7 and Allen et al., 2007a). 


\subsection{Simulating the Last Glacial Maximum glacier-climate}

\subsubsection{Creating the model Last Glacial Maximum climate}

A common endpoint for palaeo-glacier simulations is to assume that zero surface mass balance equates to steady-state conditions in the glacier-climate system (e.g. Hostetler and Clark, 2000; Plummer and Phillips 2003). This assumption means that in independent glacier-climate reconstructions a unique palaeoclimate cannot be derived for each modelled glacier because both the temperature and precipitation variables are unknown at the start of the simulation and glacier mass balance is sensitive to changes in both variables. To accommodate this uncertainty a domain of potential LGM climates was created to drive the glacier-climate model. The boundaries of the domain were $20 \%$ and $200 \%$ of present day precipitation (anomalies of $-80 \%$ to $+100 \%$ ) and temperature anomalies of $0^{\circ} \mathrm{C}$ and $-20^{\circ} \mathrm{C}$. The range in precipitation was represented by 10 precipitation totals (separated by $20 \%$ ) and the range in temperature anomalies was represented by 28 values (Allen, 2006). The climate anomalies were applied uniformly throughout the year to the CRU2.0 climate dataset (representing the climatology of 1961-1991) (New et al., 2002). A suite of 15 lapse rate combinations representing temperature lapse rates ranging from $6^{\circ} \mathrm{C} / \mathrm{km}$ (the environmental lapse rate), to $10^{\circ} \mathrm{C} / \mathrm{km}$ (the dry adiabatic lapse rate) and precipitation lapse rates ranging from $0 \mathrm{~mm} / 100 \mathrm{~m}$ and $80 \mathrm{~mm} / 100 \mathrm{~m}$, were used to downscale each potential LGM climate onto each LGM glacier profile. A correction factor equivalent to $120 \mathrm{~m}$ (Bard et al., 1990) was incorporated into the lapse rate downscaling to represent lower LGM sea levels. This method produced a total of 4200 potential LGM climates (precipitation/temperature relations), used to derive the optimum LGM climates as described in Sect. 4.2.2. The majority of proxy and model evidence suggests the LGM was a period of increased aridity compared to the present day (e.g. Gillespie and Molnar, 1995; Peyron et al., 1998; Tarasov et al., 1999; Bigelow et al., 2003; Frechen et al., 2003; Kaplan et al., 2003); however, it was noted that some GCM simulations predicted positive precipitation anomalies across LGM Europe (Fig. 7 in Kageyama et al., 2001). Therefore, positive precipitation anomalies were included to ensure that the dataset did not require extrapolation to be compared with alternative LGM climate reconstructions (Allen et al., 2007b).

\subsection{2 glacier-climate simulations}

The model climates described in Sect. 4.2.1 were used to drive a glacier-climate model based on a degree day model (DDM) of glacier surface mass balance (the model and its validation is described in Allen et al., 2007a). For each pair of lapse rates the combined precipitation and temperature anomalies that satisfied the assessment criteria for determin- ing the optimum result (described below) were assumed to be an "optimum" LGM climate. Using this approach a total of 150 "optimum" LGM palaeoclimates were derived for each region. Determining the optimum result from the domain of palaeoclimates described in Sect. 4.2.1 depended on whether the glacier-climate model was simulating mass balance over a single LGM glacier or, a region containing multiple LGM glaciers (Table 1 and 2). For single LGM glaciers the assumption of glacier-climate equilibrium at zero surface mass balance was used. For regions containing multiple glaciers the optimum LGM climate was determined using a cost function; a method of statistically comparing a spatial prediction made by a model to a control spatial distribution (cost functions are explained in Allen et al., 2007a). In this application the cost function compared the size of the accumulation area of the LGM glaciers predicted by the DDM with the accumulation area of the reconstructed LGM glacier profiles. In sites containing multiple glaciers the accumulation area was calculated from the LGM glacier profiles assuming an accumulation area ratio (AAR) of 0.67 (Benn and Evans, 1998). The LGM climate that returned the best cost function was assumed to be the optimum. A cost function was used for sites containing multiple LGM glaciers because a cumulative mass balance would have required separate glacial systems (with their different mass balance regimes) to be combined to determine the optimum LGM climate. For the Russian sites, the position and extent of the ablation zone is unknown and, as the calculation of a cumulative mass balance requires the whole glacier profile, this approach could not be applied. Palaeoclimate reconstructions derived using the cumulative mass balance and cost function methods are comparable, however, because the prescribed AAR in the cost function method is assumed to apply to a steady-state glacier profile.

The design of the modelling approach limits the reconstructed climate variables to mean annual temperature and annual precipitation, which has implications for the reliability of the climate results for two reasons. First, the mass balance of mid-latitude glaciers is primarily controlled by winter accumulation and summer ablation (Porter, 1977; Leonard, 1989). If the intensification of LGM winter conditions (e.g. Huijzer and Vandenberghe, 1998; Peyron et al, 1998; Krinner et al., 2000) is correct, the use of present day seasonality, uniform climate anomalies, and a DDM to reconstruct LGM temperatures may lead to an under-estimate of the annual temperature anomaly. DDMs are only sensitive to changes in positive air temperature (i.e. summer temperatures) which control ablation; therefore, the mean annual temperature anomalies reconstructed in this dataset primarily reflect changes in summer temperatures and do not include (potentially larger) changes to winter temperatures. Second, if it is assumed that the intensity of LGM winter precipitation was higher compared to the present day (e.g. Prentice et al., 1992; Ramrath et al., 1999), the use of present day seasonality in the DDM climate simulations would (with other things 
Sierra de Geres

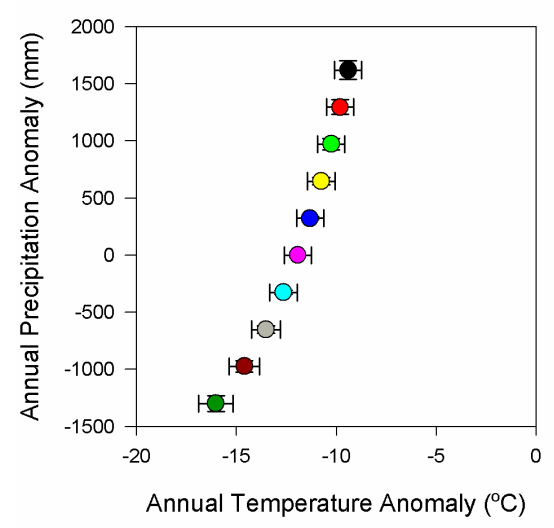

Sierra des Ancarres and Montes de Leon

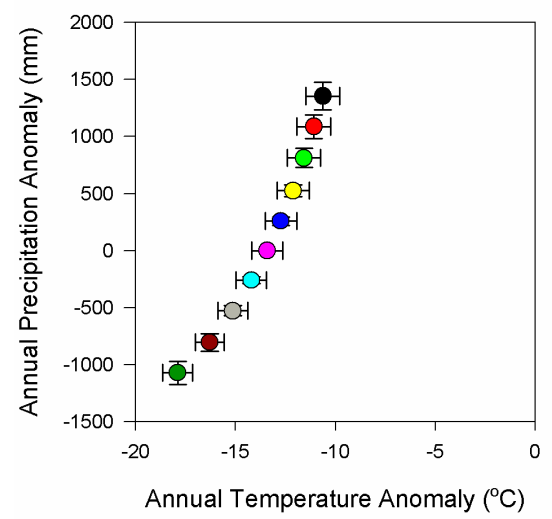

Cantabrian Mountains and Picos de Europa

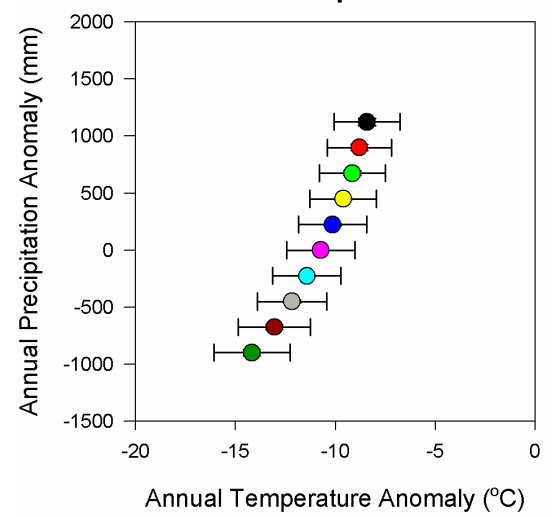

Pyrenees

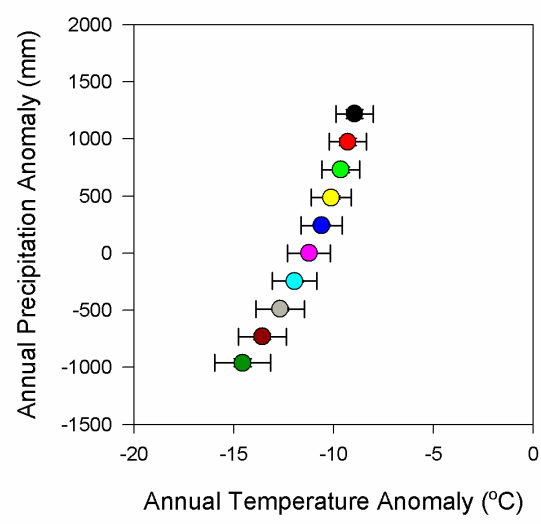

Sierra de la Demanda

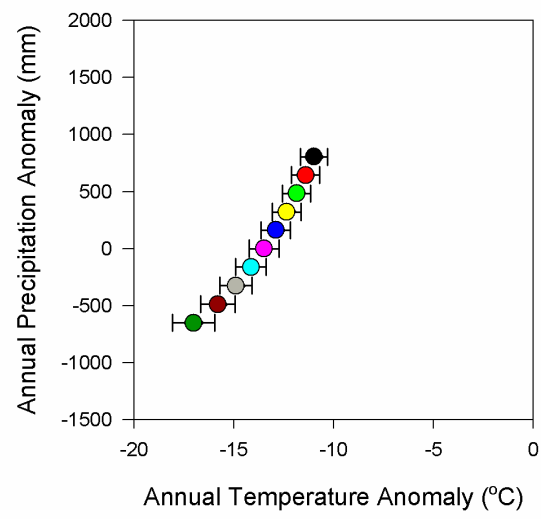

Fig. 3. Examples of LGM climate anomaly reconstructions for mountain regions in the Iberian Peninsula. The range optimum climates for each precipitation anomaly is \pm 1 standard deviation, and represents the variation in results from contributing model sites and optimum climates from different lapse rate combinations. The location of the mountain regions can be found in Fig. 1.

being equal) cause an over-estimate in the reconstructed temperature anomaly (because lower winter accumulation totals require lower temperatures to achieve steady state zero mass balance).

\section{The Last Glacial Maximum glacier-palaeoclimate dataset: Europe}

Optimum LGM precipitation anomalies ranged from $\sim 1000 \mathrm{~mm}$ drier to $\sim 1500 \mathrm{~mm}$ wetter than the present day (equating to absolute precipitation totals between $200 \mathrm{~mm}$ 


\section{Present Day Annual Precipitation}
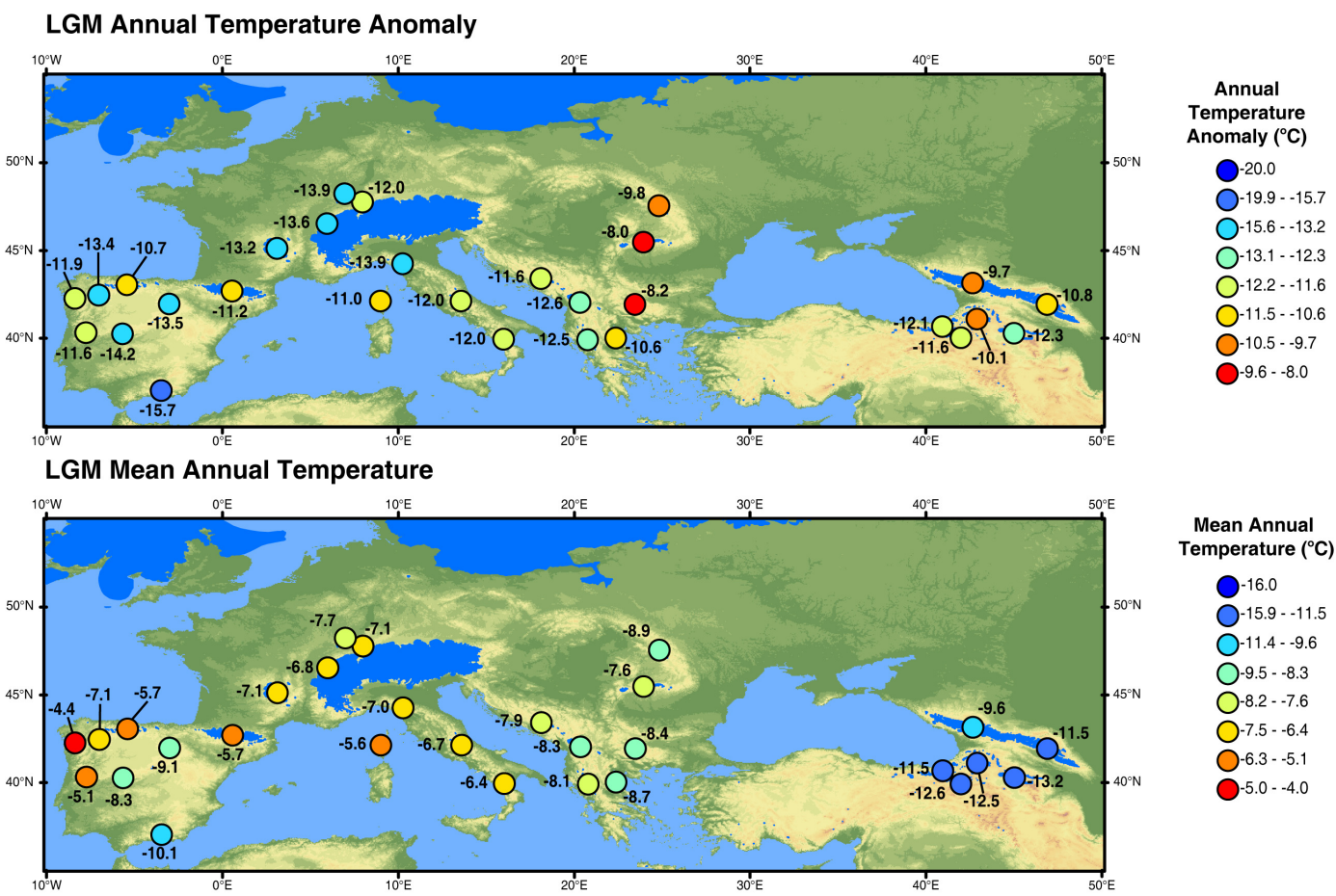

$$
\begin{gathered}
\begin{array}{c}
\text { Mean Annual } \\
\text { Temperature }\left({ }^{\circ} \mathrm{C}\right)
\end{array} \\
-16.0 \\
-15.9--11.5 \\
-11.4--9.6 \\
-9.5--8.3 \\
\bigcirc-8.2--7.6 \\
-7.5--6.4 \\
-6.3--5.1 \\
-5.0--4.0
\end{gathered}
$$

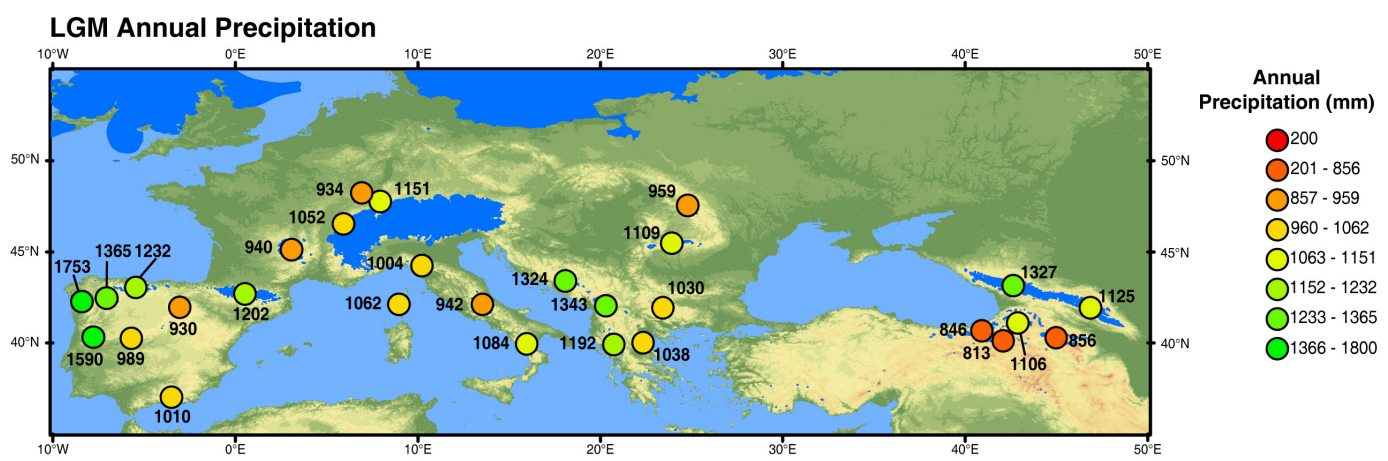

Fig. 4. Reconstructed LGM climates across Europe and Black Sea simulated using present day annual precipitation totals derived from the CRU2.0 climate dataset as the LGM annual precipitation (New et al., 2002). Reconstructions of LGM glaciers are adapted from the INQUA database (Ehlers and Gibbard, 2004a).

and $3500 \mathrm{~mm}$ ) across Europe. Temperature anomalies smaller than $-20^{\circ} \mathrm{C}$ were able to achieve optimum model result under all precipitation scenarios. The drier climates required larger temperature anomalies to achieve equilibrium surface mass balance (Fig. 3). Owing to the uncertainty in the LGM climate reconstructions it is difficult to make definitive comparisons between regions stating that one mountain region was colder, warmer, wetter or drier than another at the LGM.

If, however, for the purposes of interpretation the precipitation anomaly is calculated in percentage terms and assumed to be constant across all regions, then relative differences can be inferred. The following results are taken from the simulations using present day precipitation totals (Fig. 4). In Iberia, for example, LGM glaciated regions in close proximity to the Atlantic Ocean have smaller mean annual temperature anomalies, ranging from $-10.7^{\circ} \mathrm{C}$ to $-11.9^{\circ} \mathrm{C}$, compared to inland glaciated regions where temperature anomalies range from $-13.5^{\circ} \mathrm{C}$ to $-15.7^{\circ} \mathrm{C}$ (Figs. 1 and 4). A slight northsouth gradient in LGM mean annual temperature anomalies is present between the LGM glaciated regions north of the Alps and the LGM glaciated regions of Corsica and Italy. North of the Alps LGM temperature anomalies range from $-12.0^{\circ} \mathrm{C}$ to $-13.9^{\circ} \mathrm{C}$, in contrast to $-11.0^{\circ} \mathrm{C}$ to $-12.0^{\circ} \mathrm{C}$ in Italy. In the Balkans and Eastern Europe LGM coastal regions require larger temperature anomalies ranging from $-11.6^{\circ} \mathrm{C}$ to $-12.5^{\circ} \mathrm{C}$; in contrast, the Romanian Carpathians and Bulgarian mountains temperature anomalies range from 


\section{Precipitation $-\mathbf{4 0} \%$ of Present Day}

\section{LGM Annual Temperature Anomaly}



Annual

Temperature

$-20.0--17.6$

$-17.5--14.9$

$-14.8--13.9$

$-13.8--13.1$

$-13.0--12.7$

$-12.6--11.8$

$-11.7--10.9$

$-10.8--8.0$

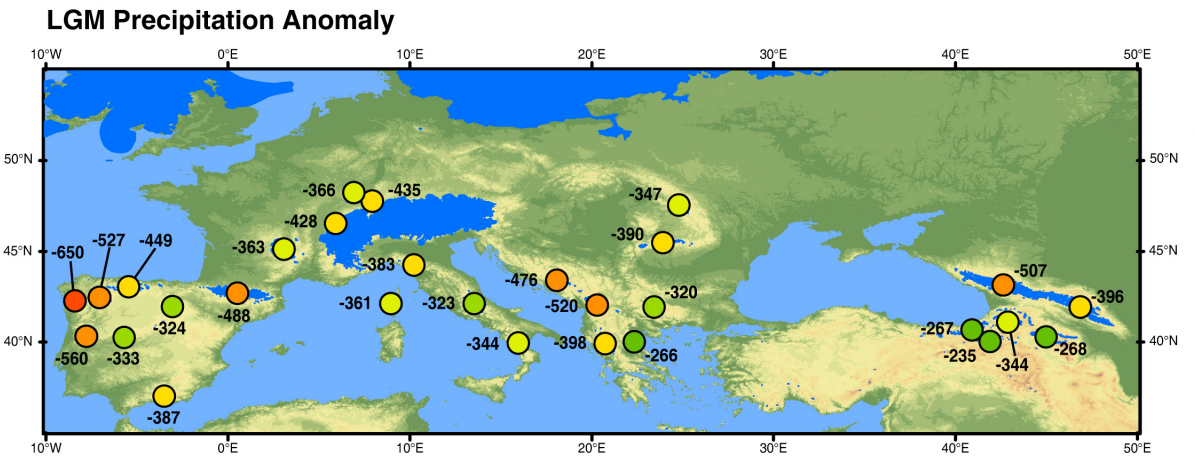

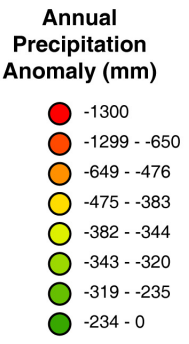

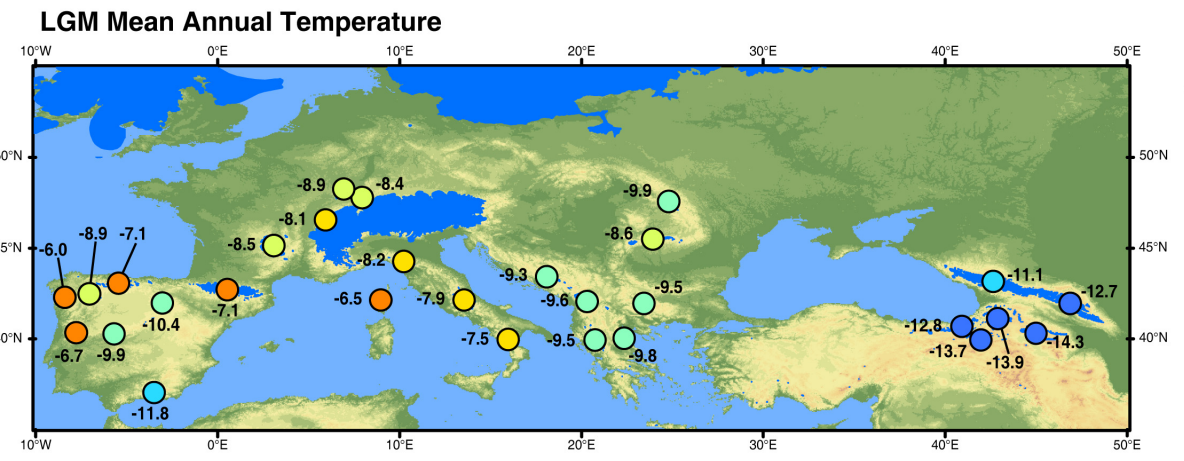

$$
\begin{gathered}
\begin{array}{c}
\text { Mean Annual } \\
\text { Temperature }\left({ }^{\circ} \mathrm{C}\right)
\end{array} \\
\qquad \begin{array}{l}
-16.0 \\
\bigcirc
\end{array} \\
-15.9--12.7 \\
\bigcirc-12.6--11.1 \\
\bigcirc-11.0--9.3 \\
\bigcirc-9.2--8.4 \\
\bigcirc-8.3--7.5 \\
\bigcirc-7.4--6.0 \\
\bigcirc-5.9--4.0
\end{gathered}
$$

\section{LGM Annual Precipitation}
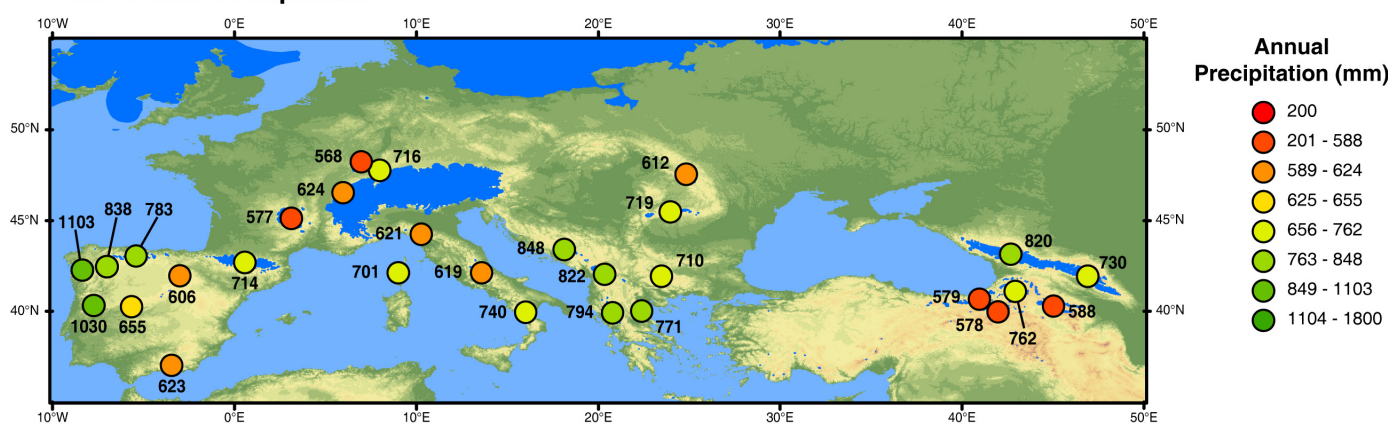

Fig. 5. Reconstructed LGM climates across Europe and Black Sea simulated using $-40 \%$ of present day annual precipitation totals derived from the CRU2.0 climate dataset (New et al., 2002). Reconstructions of LGM glaciers are adapted from the INQUA database (Ehlers and Gibbard, 2004a). 


\section{Precipitation $-80 \%$ of Present Day}

\section{LGM Annual Temperature Anomaly}

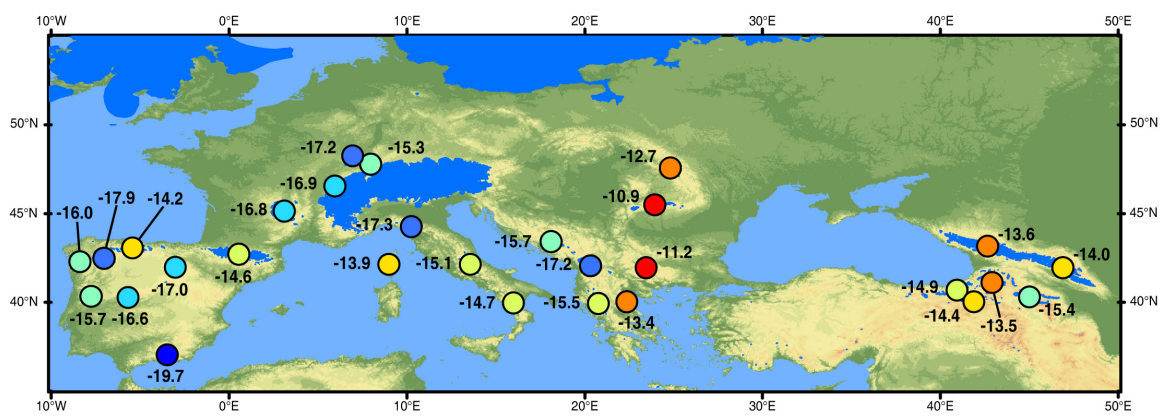

Annua

Temperature
Anomaly $\left({ }^{\circ} \mathrm{C}\right)$

$-20.0--19.7$

$-20.0--19.7$
$-19.6--17.2$

$-17.1--16.6$

$-16.5--15.3$

- $-15.2--14.6$

$-14.5--13.9$

$-13.8--12.7$

$-12.6--8.0$

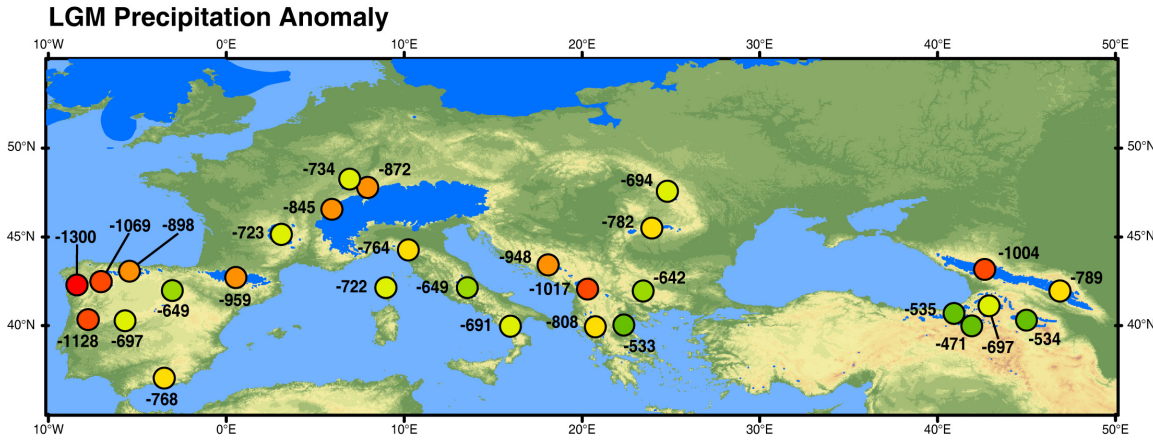

Annual

Precipitation Anomaly $(\mathrm{mm})$

O -1300

O $-1299--1004$

$-1003--845$

O $-844--764$

O $-763--691$

O $-690--642$

- $-641--471$

○ -470 - 0

LGM Mean Annual Temperature

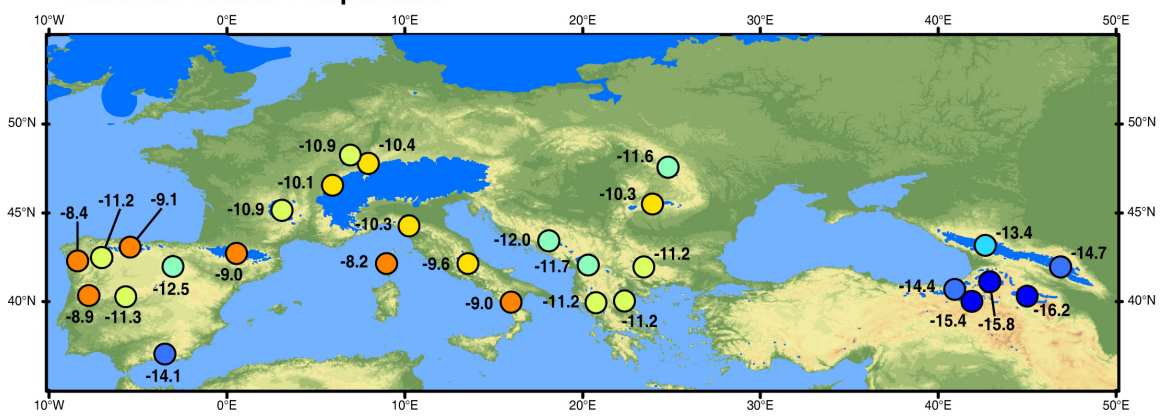

Mean Annual Temperature $\left({ }^{\circ} \mathrm{C}\right)$

$-16.2--15.4$

- $15.3--14.1$

O $-14.0--13.4$

O $-13.3--11.6$

O $-11.5--10.9$

O $-10.8--9.6$

O $-9.5-8.2$

O $-8.1--4.0$

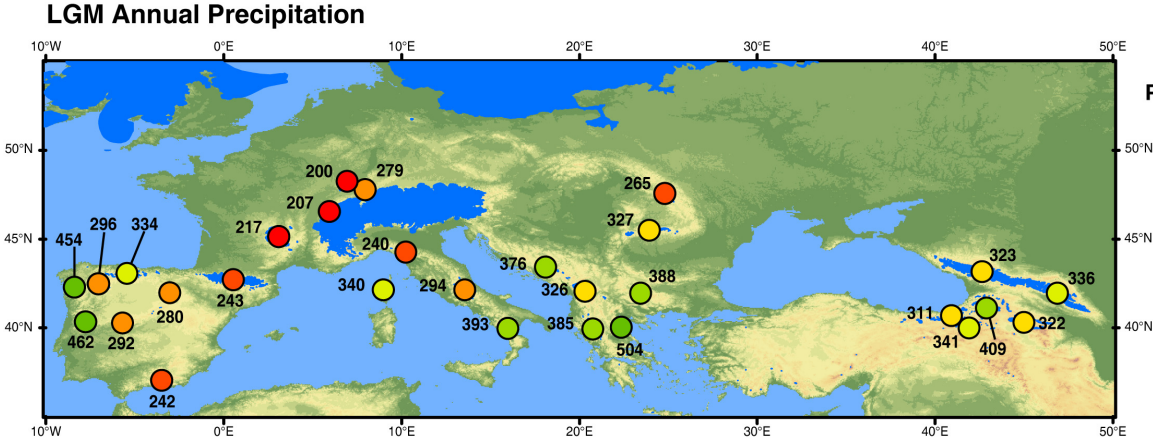

Annual Precipitation (mm)

O 200-217

○ $218-265$

○ $266-296$

O $297-327$

O 328 - 341

O $342-409$

O $410-504$

O $505-1800$

Fig. 6. Reconstructed LGM climates across Europe and Black Sea simulated using $-80 \%$ of present day annual precipitation totals derived from the CRU2.0 climate dataset (New et al., 2002). Reconstructions of LGM glaciers are adapted from the INQUA database (Ehlers and Gibbard, 2004a). 
Arctic Urals 1

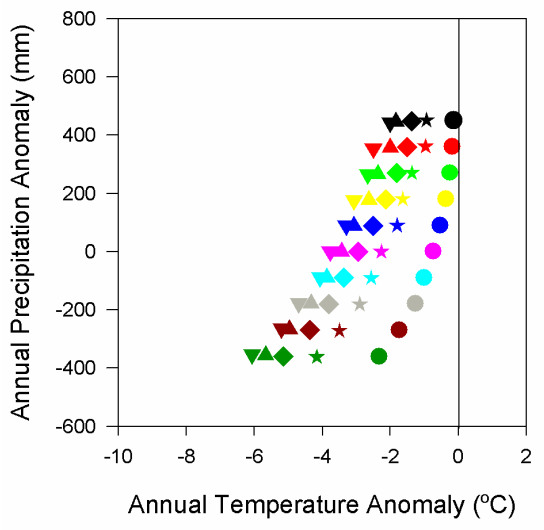

Central Urals 1

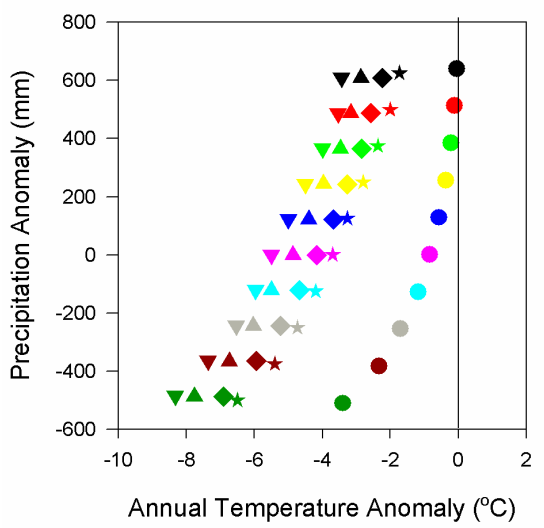

Central Urals 3

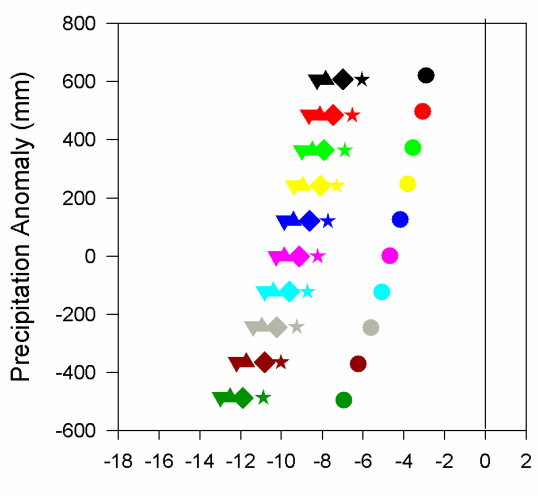

Annual Temperature Anomaly $\left({ }^{\circ} \mathrm{C}\right)$
Arctic Urals 2

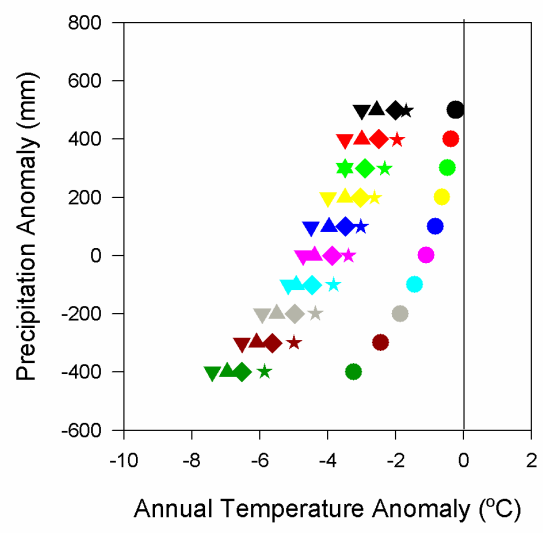

Central Urals 2

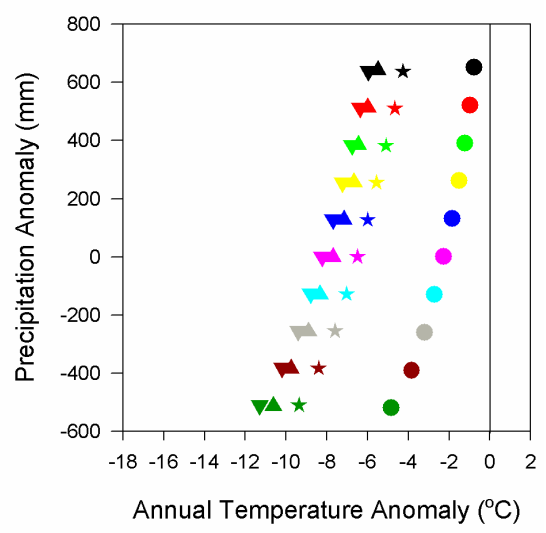

Southern Urals 1

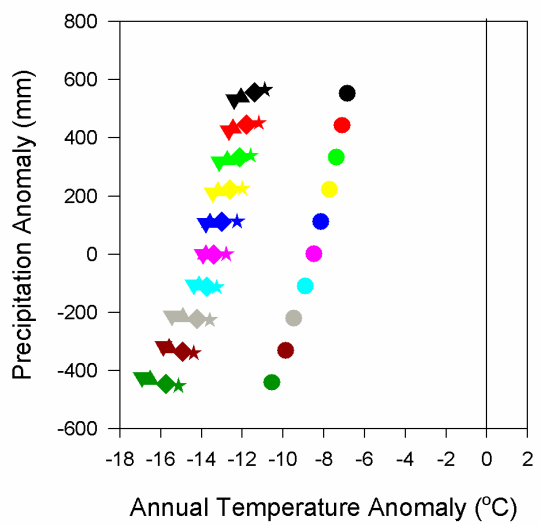

Fig. 7. LGM climate anomalies reconstructed over the Ural Mountains. The colours represent different precipitation anomalies ranging from $+100 \%$ to $-80 \%$ of present day (the colour gradation is the same as Fig. 3. The shapes represent the different glacial extents considered by the glacier-climate model $($ circle $=0 \%$, star $=1 \%$, diamond $=2 \%$, triangle $=4 \%$, inverted triangle $=6 \%$ ).

$-8.0^{\circ} \mathrm{C}$ to $-9.8^{\circ} \mathrm{C}$. Across the Eastern Black Sea LGM annual temperature anomalies range from $-9.7^{\circ} \mathrm{C}$ to $-12.3^{\circ} \mathrm{C}$. Figures 5 and 6 show the same results as Fig. 4, but for precipitation anomalies of $-40 \%$ and $-80 \%$, respectively. Larger negative percentage precipitation anomalies cause an- nual temperature anomalies to increase (Figs. 5 and 6); however the relative trends between regions described in the simulation using present day precipitation totals remain. 


\section{The LGM glacier-palaeoclimate dataset: Russia}

Assuming present day precipitation, the temperature anomaly needed for the $0 \%$ glacial coverage simulations can be interpreted as representing the cooling necessary (within the present day climate) at the onset of glaciation. In the Ural Mountains this threshold exhibits a strong latitudinal gradient (Fig. 7). In the Arctic Urals the onset of glaciation is initiated after a cooling of $-1^{\circ} \mathrm{C}$ but a cooling of $-8^{\circ} \mathrm{C}$ is required in the Southern Urals. In the Puterana Plateau the results are similar to the Arctic Urals, a cooling of only $-0.5^{\circ} \mathrm{C}$ is required to initiate the onset of glaciation (i.e. small valley glaciers, assuming present day precipitation) (Fig. 8). In all regions, increasing the extent of LGM glaciation increases the size of the temperature anomaly required to achieve optimum cost-function conditions (Figs. 7 and 8); for example temperature anomalies for the INQUA Puterana Plateau ice cap (Ehlers and Gibbard, 2004a) and prescribed 6\% glacial coverage simulation (assuming present day precipitation) are $-8.5^{\circ} \mathrm{C}$ and $-4.5^{\circ} \mathrm{C}$, respectively (Fig. 8).

\section{Discussion}

The characteristics of ideal proxy palaeo-datasets were described in Sect. 2 and are a suitable framework for discussing the palaeoclimate (temperature and precipitation) dataset presented in this paper. The first desirable characteristic is a continental to global scale resolution to ensure that regional trends are resolved (Kohfeld and Harrison, 2000). The dataset presented here contains potential LGM temperature/precipitation relationships for thirtysix upland regions; this density is similar to previous proxy climate reconstructions across Europe (Peyron et al., 1998; Tarasov et al., 1999). It is well known that the relationship between an individual glacier and the surrounding regional climate is modulated by local scale factors (e.g. Kerr, 1993; Mark et al., 2005). Therefore the LGM climate signal for each region was derived from the average of the results from the individual glacier-climate simulations. In Western Europe reconstructed temperature anomalies can be divided into three main regions: north of the Alps, the Mediterranean Basin, and Eastern Europe. With a precipitation anomaly of $-40 \%$, mean temperature anomalies ( \pm one standard deviation) for these three regions are $-15 \pm 0.3^{\circ} \mathrm{C},-13 \pm 0.8^{\circ} \mathrm{C}$, and $-10 \pm 1^{\circ} \mathrm{C}$, respectively. The temperature anomaly of $-12.5 \pm 1^{\circ} \mathrm{C}$ for the Eastern Black Sea region is comparable with the Mediterranean Basin.

In Russia, DDM simulations were used to assess the potential likelihood of LGM glaciation in the Ural Mountains and Puterana Plateau. The potential decrease in temperature before the onset of glacerization in the Northern Urals is less than $3.0^{\circ} \mathrm{C}$, even under the largest negative precipitation anomalies; this suggests that it was unlikely that this region was not glaciated at the LGM. Supporting this conclu- sion are data describing 20th Century glaciers in the Northern Ural Mountains (e.g. Grosval'd and Kotlyakov, 1969; National Snow and Ice Data Center, 1999). In the Southern Urals, a cooling of $-10^{\circ} \mathrm{C}$ was possible before the DDM predicted glacierization, which suggests glaciation of the Ural Mountains during the LGM did not reach the Southern Urals. In the Puterana Plateau the present day climate can only be cooled by $-0.5^{\circ} \mathrm{C}$ before the onset of glacierization, which combined with the existence of present day glaciers in the region (National Snow and Ice Data Center, 1999) leads to the conclusion that the Puterana Plateau must have been glaciated (by at least valley glaciers) at the LGM. Temperature anomalies reconstructed from the different percentage glacial extents and INQUA ice cap range from $-2.6^{\circ} \mathrm{C}$ at the $1 \%$ glacial coverage to $-8.6^{\circ} \mathrm{C}$ from the INQUA ice cap simulation, assuming present day precipitation totals. The INQUA LGM glacier dataset (Ehlers and Gibbard, 2004a) suggests that the Northern Urals were not glaciated and the Puterana Plateau heavily glaciated at the LGM. The results have demonstrated that in order to achieve this distribution of large-scale LGM glaciers requires virtually no change in the present day climate of the Northern Urals, but a comparatively large cooling over the Puterana Plateau (in contrast to the formation of merely small glaciers in this region). This distribution of temperature anomalies is not found in the pollen climate reconstructions: temperature anomalies range from $-5^{\circ} \mathrm{C}$ to $-8^{\circ} \mathrm{C}$, and $-1^{\circ} \mathrm{C}$ to $-3^{\circ} \mathrm{C}$ in the Ural Mountains and Puterana Plateau, respectively (Tarasov et al., 1999). It is concluded, from DDM simulations and pollen data, that the Ural Mountains and Puterana Plateau were both probably glaciated by small discrete mountain glaciers during the LGM as proposed by Astakhov (1997) and Svendsen et al. (2004).

The second characteristic of the ideal proxy palaeo-dataset is that the data should be directly compatible with model output (Kohfeld and Harrison, 2000; Harrison, 2003). The DDM is driven by climate variables that are directly compatible with GCM output, and this relation is expanded in Allen et al. (2007a).

The third characteristic of the ideal proxy palaeo-dataset is transparency in the primary data (Harrison, 2003). The primary data are readily available to the scientific community via the INQUA Quaternary glacier GIS (Ehlers and Gibbard, 2004a).

The fourth characteristic is a detailed documentation describing the methods used, assumptions made, and any data transformations (Harrison, 2003). Details of the DDM, meteorological baseline, data transformations and verification of the methodology can be found in Allen et al. (2007b). Details of the transformation required to make the INQUA LGM glacier dataset compatible with the other input data have been detailed in this paper. The model results under optimum LGM climates show that the modelling approach consistently predicted plausible first order glaciological and climatic conditions. 


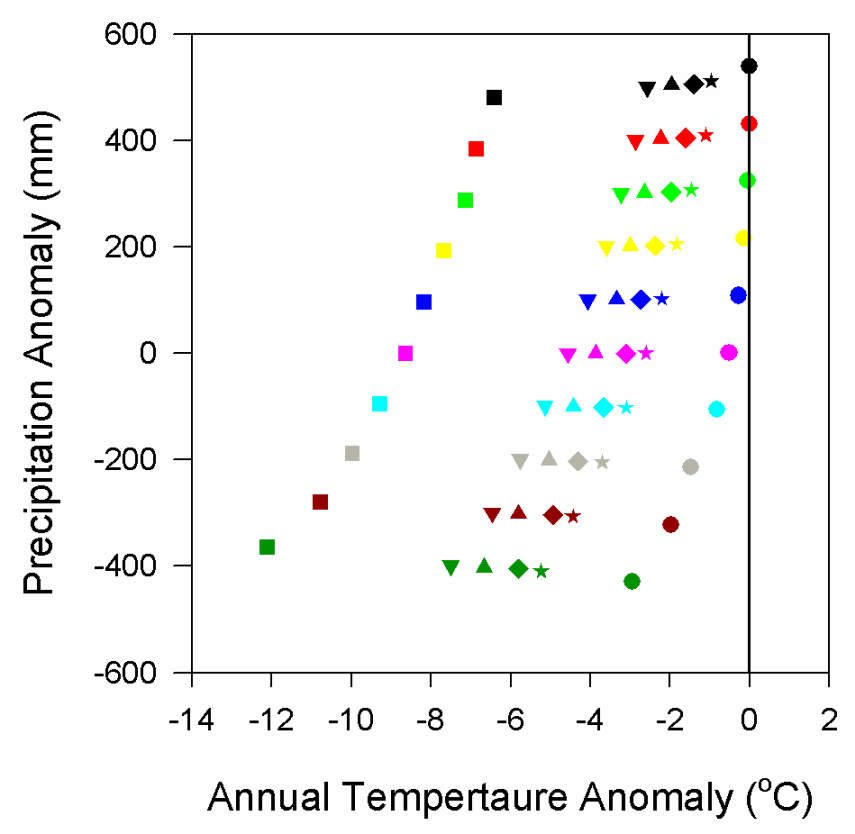

Fig. 8. LGM climate anomalies reconstructed over the Puterana Plateau. The colours represent different precipitation anomalies ranging from $+100 \%$ to $-80 \%$ of present day (the colour gradation is the same as Figure 3. The shapes represent the different glacial extents considered by the glacier-climate model ( circle $=0 \%$, star $=1 \%$, diamond $=2 \%$, triangle $=4 \%$, inverted triangle $=6 \%$, square $=$ INQUA LGM ice cap).

The fifth characteristic for proxy datasets is the provision of adequate metadata describing specific details of the individual sites, and the chronological framework used to date the proxy evidence (Kohfeld and Harrison, 2000; Harrison, 2003). Metadata describing the glacial style, glacial extent, snowline depressions, and available chronological information for the glaciated regions of Europe included in the INQUA glacier dataset can be found in Ehlers and Gibbard (2004a). Recent work on sub-tropical glaciers has emphasised the importance of reliable absolute dating when using glacial-geological evidence for climate model comparisons (e.g. Benn et al., 2005; Mark et al., 2005; Smith et al., 2005). Such dating is especially important when comparing palaeoclimate results from regions in which the glaciers did not reach a maximum during the global LGM (e.g. Gillespie and Molnar, 1995; Ono et al., 2005). The available dating evidence accompanying the INQUA European glacier dataset (Ehlers and Gibbard, 2004a and references therein) does not currently meet the standard of the tropical glacier studies (Benn et al., 2005; Mark et al., 2005; Smith et al., 2005). Absolute dates for LGM glaciers are only available in a few regions, e.g. the Vosges Mountains, Jura Mountains, and Central Italian Apennines (Campy and Richards, 1988; Dricot et al., 1991; Giraudi, 2004). In the remaining regions the geological evidence is inferred as LGM from relative chronologies, e.g. Massif Central, and Romanian Carpathi- ans (Gillespie and Molnar, 1995; Urdea, 2004), or simply assumed to be LGM, e.g. the mountains of the Former Yugoslavia, and Mountain glaciations in Iberia (Straus, 1992; Marjanac and Marjanac, 2004). In several regions these nondated reconstructions have placed the maximal glacial advance in the geological record at the LGM, which are subsequently used in the INQUA dataset (Ehlers and Gibbard, 2004a). There is a growing body of evidence that suggests that the LGM glacial advance was smaller than the maximum advance found in the geological record. For example, in Greece preliminary uranium dating places the maximal glacial advance to earlier in the Last Glaciation and suggests that the LGM glaciation was less extensive (Woodward et al., 2004). Dating work has placed the LGM glaciation in the Cantabrian Mountains inside the maximal advance (Sanchez and Arquer, 2002). In the Pyrenees, the glacial reconstruction prescribed to the LGM by the INQUA dataset is the maximal advance during the Last Glaciation, which has been radiocarbon dated to before the LGM (Herail et al., 1986; Andrieu et al., 1988; Jalut et al., 1988; Vilaplana and Montserrat, 1989; Jalut et al., 1992; García-Ruiz et al., 2003). As the INQUA glacier dataset has used the largest Late-Quaternary glacial advance for the LGM glacier profile in regions where no absolute chronology is currently available the LGM temperature anomalies should be treated as a maximum. "Reconstructing the former extent of glaciers requires detailed geomorphic mapping and the analysis of landforms and sediments" (Benn et al., 2005, p. 11); such detail is required because the destruction of older glacial evidence by more recent glacial advances, periglacial activity, and post deglaciation landform erosion makes glacial-geological evidence a naturally incomplete record. It has been implicitly assumed in this modelling study that the analysis and interpretation of the glacial-geological evidence contributing to the INQUA dataset (Ehlers and Gibbard, 2004a) has been done in a consistent manner and is correct. There are also a small number of regions where the glacier reconstruction has been incorrectly reproduced in the INQUA GIS dataset, e.g. in the Sierra Nevada Mountains the glacial extent is represented by a series of overlapping triangles that have no recognisable glacial attributes.

The final characteristic is the presentation of results on a site by site basis. The glacier-climate dataset is presented in a site by site format, thus ensuring that no interpolation of data has been made.

\section{Conclusions}

A dataset of 36 new and independent LGM European precipitation/temperature relationships derived from European Quaternary glaciers has been described. It was designed to be fully independent of alternative LGM climate reconstructions to maximise its potential use in future LGM climate assessment studies. Regional climate estimates were 
constructed by combining the results of glacier-climate simulations of the individual LGM glaciers within the region. Owing to the independent nature of the dataset it was not possible to simulate a unique solution for each region, therefore a suite of optimum LGM temperatures were derived for prescribed precipitation conditions ranging from $-80 \%$ to $+100 \%$ of present day annual precipitation. In Europe regional trends are evident in the temperature anomalies (assuming a fixed percentage precipitation anomaly), with larger temperature anomalies found north of the Alps compared to the Mediterranean Basin (Figs. 5-7). In Northern Russia the model results suggest that both the Ural Mountains and Puterana Plateau were glaciated with small mountain glaciers during the LGM.

This dataset will enable glacial-geological evidence to contribute to our understanding of the European climate at the continental scale (Allen et al., 2007b). Moreover this work has developed and tested a new and simple method which is transferable to other regions of the world; the appropriate glacial-geological data for the rest of the world required by the glacier-climate model are available in Volumes II and III of the INQUA Quaternary glacier dataset (Ehlers and Gibbard, 2004b; Ehlers and Gibbard, 2004c).

\section{Appendix A}

$\begin{array}{ll}\text { AAR } & \text { Accumulation Area Ratio } \\ \text { CLIMAP } & \begin{array}{l}\text { Climate/Long Range Investigation } \\ \text { Mapping and Predictions Project }\end{array} \\ \text { CRU } & \begin{array}{l}\text { Climate Research Unit - University of } \\ \text { East Anglia }\end{array} \\ \text { DDM } & \text { Degree Day Model } \\ \text { DEM } & \text { Digital Elevation Model } \\ \text { GCM } & \text { General Circulation Model } \\ \text { GIS } & \text { Geographical Information System } \\ \text { INQUA } & \text { International Quaternary Association } \\ \text { LGM } & \text { Last Glacial Maximum } \\ \text { PMIP } & \text { Palaeoclimate Modelling } \\ & \text { Intercomparison Project } \\ \text { USGS } & \text { United States Geological Service }\end{array}$

Acknowledgements. This work was funded by a NERC studentship. We thank two anonymous referees and the editor, Marie-France Loutre, for helpful and constructive advice. Robert Allen would like to thank Martin Siegert and Tony Payne for their support and advice during the period of this research.

Edited by: M.-F. Loutre

\section{References}

Allen, R. J., Siegert, M. J., and Payne, T.: Reconstructing glacierbased climates of LGM Europe and Russia - Part 1: numerical modelling and validation methods, Clim. Past Discuss., 3,, 1133 1166, 2007a.

Allen, R. J., Siegert, M. J. and Payne, T.: Reconstructing glacierbased climates of LGM Europe and Russia - Part 3: Comparison with alternative palaeoclimate reconstructions, Clim. Past Discuss., 3, 1199-1233, 2007b, http://www.clim-past-discuss.net/3/1199/2007/.

Allen, R. J.: Reconstructing the Last Glacial Maximum Climate of Europe and Russia using the Glacial-Geological Record, PhD Thesis, School of Geographical Sciences, University of Bristol, 304 pp., 2006.

Andrieu, V., Hubschman, J., Jalut, G., and Herail, G.: Chronologie de la déglaciation des Pyrénées françaises, B. Assoc. Fr. Etud. Quat., 2/3, 55-67, 1988.

Astakhov, V. I.: Late Glacial Events in the Central Russian Arctic, Quatern. Int., 41/42, 17-26, 1997.

Astakhov, V. I.: Pleistocene ice limits in the Russian northern lowlands, edited by: Ehlers, J. and Gibbard, P. L., in: Quaternary Glaciations - Extent and Chronology Part I: Europe. 309-320, 2004.

Bard, E., Hamelin, B., and Fairbanks, R. G.: U-Th ages obtained by mass spectrometry in corals from Barbados: sea level during the past 130000 years, Nature, 346, 456-458, 1990.

Benn, D. I. and Evans, D. J. A.: Glaciers and Glaciation, Edward Arnold, London, UK, 734 pp., 1998.

Benn, D. I., Owen, L. A., Osmaston, H. A., Seltzer, G. O., Porter, S. C., and Mark, B.: Reconstructions of equilibrium-line altitudes for tropical and sub-tropical glaciers, Quatern. Int, 138-139, 821, 2005.

Bigelow, N. H., Brubaker, L. B., Edwards, M. E., Harrison, S. P., Prentice, I. C., Anderson, P. M., Andreev, A. A., Bartlein, P. J., Christensen, T. R., Cramer, W., Kaplan, J. O., Lozhkin, A. V., Matveyeva, N. V.,. Murray, D. F., McGuire, A. D., Razzhivin, V. Y., Ritchie, J. C., Smith, B., Walker, D. A., Gajewski, K., Wolf, V., Holmqvist, B. H., Igarashi, Y., Kremenetskii, K., Paus, A., Pisaric, M. J. F., and Volkova, V. S. L.: Climate change and Arctic ecosystems: 1 . Vegetation changes north of $55^{\circ} \mathrm{N}$ between the last glacial maximum, mid-Holocene, and present, J. Geophys. Res., 108, ALT 11, 2003.

Boulton, G. S.: Glacial history of the Spitzbergen archipelago and the problem of the Barents Sea ice sheet, Boreas, 8, 31-57, 1979.

Braconnot, P., Otto-Bliesner, B., Harrison, S., Joussaume, S., Peterchmitt, J.-Y., Abe-Ouchi, A., Crucifix, M., Driesschaert, E., Fichefet, Th., Hewitt, C.D., Kageyama, M., Kitoh, A., Laîné, A., Loutre, M.-F. Marti, O., Merkel, U., Ramstein, G., Valdes, P., Weber, S.L., Yu, Y., Zhao, Y. Results of PMIP2 coupled simulations of the Mid-Holocene and Last Glacial Maximum - Part 1: experiments and large-scale features, Clim. Past, 3, 261-277, 2007 , http://www.clim-past.net/3/261/2007/.

Buoncristiani, J.-F. and Campy, M.: Late Pleistocene detrital sediment yield of the Jura glacier, France, Quatern. Res., 56, 51-61, 2001.

Calvet, M.: The Quaternary glaciation of the Pyrenees, in: Quaternary Glaciations - Extent and Chronology Part I: Europe, edited by: Ehlers, J. and Gibbard, P. L., 119-128, 2004. 
Campy, M. and Richards, H.: Modalités et chronologie de la déglaciation Wurmienne dans la chaîne Jurassieme, B. Assoc. Fr. Etud. Quat., 2/3, 81-90, 1988.

CLIMAP Project Members: Seasonal reconstruction of the Earth's surface at the Last Glacial Maximum, Geological Society of America, Map and Chart Series, MC-36-1981, 1981.

Denton, G. H. and Hughes, T. J.: The Arctic ice sheet: an outrageous hypothesis, in: The Last Great Ice Sheets, edited by: Denton G. H. and Hughes, T. J., Wiley, New York, 440-467, 1981.

Dricot, E., Pétillon, M., and Seret, G.: When and why did glaciers grow or melt in the Vosges Mountains (France)?, in: Klimageschichtliche Probleme der Letzten 130000 Jahre, edited by: Frenzel, B.,363-376, Palaöklimaforschung, Gustav Fischer Verlag, Stuttgart, 1991.

Ehlers, J. and Gibbard, P. L.: Quaternary Glaciations - Extent and Chronology, Part I: Europe Series, in: Developments in Quaternary Science 2, edited by: Rose J., Elsevier, London, 488 pp., 2004a.

Ehlers, J. and Gibbard, P. L.: Quaternary Glaciations - Extent and Chronology, Part II: North America Series, in: Developments in Quaternary Science 2, edited by: Rose J., Elsevier, London, 450 pp., 2004b.

Ehlers, J. and Gibbard, P.L.: Quaternary Glaciations - Extent and Chronology, Part III: South America, Asia, Africa, Australia, and Antarcticain: Developments in Quaternary Science 2, edited by: Rose J., Elsevier, London, 433 pp., 2004c.

Farerra, I., Harrison, S. P., Prentice, I. C., Ramstein, G., Guiot, J., Bartlein, P. J., Bonnefille, R., Bush, M., Cramer, W., von Grafenstein, U., Holmgren, K., Hooghiemstra, H., Hope, G., Jolly, D., Lauritzen S.-E., Ono, Y., Pinot, S., Stute, M., and Yu, G.: Tropical climates at the Last Glacial Maximum: a new synthesis of terrestrial palaeoclimate data, 1. Vegetation, lake-levels and geochemistry, Clim. Dynam., 15, 823-856, 1999.

Florineth, D. and Schlüchter, C.: Alpine evidence for atmospheric circulation patterns in Europe during the Last Glacial Maximum, Quatern. Res., 54, 295-308, 2000.

Frechen, M., Oches, E. A., and Kohfeld, K. E.: Loess in Europe mass accumulation rates during the Last Glacial Period, Quatern. Sci. Rev., 22, 1835-1857, 2003.

García-Ruiz, J. M., Valero-Garcés, B. L., Martí-Bono, C., and González-Sampériz, P.: Asynchroneity of maximum glacier advances in the central Spanish Pyrenees, J. Quatern. Sci., 18, 6172, 2003.

Gillespie, A. and Molnar, P.: Asynchronous maximum advances of mountain and continental glaciers, Rev. Geophys., 33, 311-364, 1995.

Giraudi, C.: The Apennine glaciations in Italy, in: Quaternary Glaciations - Extent and Chronology Part I: Europe, edited by: Ehlers, J. and Gibbard, P. L., 215-224, 2004.

Gobejishvili, R.: Late Pleistocene (Würmian) glaciation of the Caucasus, in: Quaternary Glaciations - Extent and Chronology Part I: Europe, edited by: Ehlers, J. and Gibbard, P. L., 129-134, 2004.

Grosval'd, M. G. and Kotlyakov, V. M.: Present day glaciers in the USSR and some data on their mass balance, J. Glaciol., 8, 9-21, 1969.

Harrison, S. P.: Contributing to global change science: the ethics, obligations and opportunities of working with palaeoenvironmental databases. Norsk Geografisk Tidsskrift, 57, 1-8. 2003.
Harrison, S.P., Braconnot, P., Joussaume, S., Hewitt, C., and Stouffer, R. J.: Comparison of palaeolcimate simulations enhances confidence in models, EOS, Trans. AGU, 83, 447, 2002.

Herail, G., Hubschman, J., and Jalut, G.: Quaternary glaciations in the French Pyrenees, Quatern. Sci. Rev., 5, 397-402, 1986.

Hostetler, S. W. and Clark, P. U.: Tropical climate at the last glacial maximum inferred from glacier mass-balance modelling. Science, 290, 1747-1750, 2000.

Hubberten, H. W., Andreev, A., Astakhov, V. I., Demidov, I., Dowdeswell, J. A., Henriksen, M., Hjort, C., Houmark-Nielsen, M., Jakobsson, M., Kuzmina, S., Larsen, E., Lunkka, J. P., Lyså, A., Mangerud, J., Möller, P., Saarnisto, M., Schirrmeister, L., Sher, A. V., Siegert, C., Siegert, M. J., and Svendsen, J. I.: The periglacial climate and environment in northern Eurasia during the Last Glaciation, Quatern. Sci. Rev., 23, 1333-1357, 2004.

Huijzer, B. and Vandenberghe, J.: Climatic reconstruction of the Weichselian Pleniglacial in northwestern and central Europe, J. Quatern. Sci., 13, 391-417, 1998.

Jalut, G., Monserrat Marti, J., Fontugne, M., Delibrias, G., Vilaplana, J. M., and Julia, R.: Glacial to interglacial vegetation changes in the northern and southern Pyrenees: deglaciation, vegetation cover and chronology, Quatern. Sci. Rev., 11, 449480, 1992.

Jalut, G., Andrieu, V., Delibrias, G., Fontugne, M., and Pagès, P.: Palaeoenvironment of the valley of Ossau (Western French Pyrenees) during the last 27000 years, Pollen et Spores, 30, 357-393, 1988.

Jost, A., Lunt, D., Kageyama, M., Abe-Ouchi, A., Peyron, O., Valdes, P. J. and Ramstein, G.: High resolution simulations of the last glacial maximum climate over Europe: a solution to discrepancies with continental palaeoclimate reconstructions?, Clim. Dynam., 24, 577-590, 2005.

Joussame, S. and Taylor, K. E.: Status of the Paleoclimate Modelling Intercomparison Project (PMIP), in: Proceedings of the first international AMIP scientific conference, Monterrey, California, USA, 15-19 May, WRCP-92, 425-430, 1995.

Kageyama, M., Peyron, O., Pinot, S., Tarasov, P., Guiot, J., Joussaume, S., and Ramstein, G.: The Last Glacial Maximum climate over Europe and western Siberia: a PMIP comparison between models and data, Clim. Dynam., 17, 23-43, 2001.

Kageyama, M., Harrison, S. P., and Abe-Ouchi, A.: The depression of tropical snowlines at the last glacial maximum: What can we learn from climate model experiments?, Quatern. Int., 138-139, 202-219, 2005.

Kaplan, J. O., Bigelow, N. H., Prentice, I. C., Harrison, S. P., Bartlein, P. J., Christensen, T. R., Cramer, W., Matveyeva, N. V., McGuire, A. D., Murray, D. F., Razzhivin, V. Y., Smith, B., Walker, D. A., Anderson, P. M., Andreev, A. A., Brubaker, L. B., Edwards, M. E., and Lozhkin, A. V.: Climate change and Arctic ecosystems: 2. Modeling, paleodata-model comparisons, and future projections, J. Geophys. Res., 108(D19), 8171, doi:10.1029/2002JD002559, 2003.

Kerr, A.: Topography, climate and ice masses - a review, Terra Nova, 5, 332-342, 1993.

Kohfeld, K. E. and Harrison, S. P.: How well can we simulate past climates? Evaluating the models using global palaeoenvironmental datasets. Quatern. Sci. Rev., 19, 321-346, 2000.

Krinner, G., Raynaud, D., Doutrriaux, C., and Dang, H.: Simulations of the Last Glacial Maximum ice sheet surface climate: 
Implications for the interpretation of ice core air, J. Geophys. Res., 105, 2059-2070, 2000.

Leonard, E. M.: Climatic change in the Colorado Rocky Mountains: estimates based on the modern climates at Late Pleistocene equilibrium lines, Arctic Alpine Res., 21, 245-255, 1989.

Marjanac, L. and Marjanac, T.: Glacial history of the Croatian Adriatic and Coastal Dinarides, in: Quaternary Glaciations - Extent and Chronology Part I: Europe, edited by: Ehlers, J. and Gibbard, P. L., 19-26, 2004.

Mark, B. G., Harrison, S. P., Spessa, A., New, M., Evans, D. J. A., and Helmens, K. F.: Tropical snowlines changes at the last glacial maximum: A global assessment, Quatern. Int., 138-139, 168-201, 2005.

National Snow and Ice Data Center: World Glacier Inventory, World Glacier Monitoring Service and National Snow and Ice Data Center/World Data Center for Glaciology, Boulder, CO, USA, Digital Media, 1999.

New, M., Lister, D., Hulme, M., and Makin, I.: A high-resolution data set of surface climate over global land areas, Climate Res., 21, 1-25, 2002.

Ono, Y., Aoki, T., Hasegawa, H., and Dali, L.: Mountain glaciation in Japan and Taiwan at the global Last Glacial Maximum, Quatern. Int., 138-139, 79-92, 2005.

Owen, L. A. and Benn, D. I.: Equilibrium-line altitudes of the Last Glacial Maximum for the Himalaya and Tibet: an assessment and evaluation of results, Quatern. Int., 138-139, 55-78, 2005.

Peyron, O., Guiot, J., Cheddadi, R., Tarasov, P., Reille, M., de Beaulieu, J.-L., Bottema, S., and Andrieu, V.: Climatic reconstruction in Europe for $18000 \mathrm{yr}$ BP from pollen data, Quatern. Res., 49, 183-196, 1998.

Plummer, M. A. and Phillips, F. M.: A 2-D numerical model of snow/ice energy balance and ice flow for paleoclimate interpretation of glacial geomorphic features, Quatern. Sci. Rev., 22, 1389-1406, 2003.

Porter, S. C.: Present and past glaciation threshold in the Cascade Range, Washington, USA: Topographic and climatic controls and paleoclimatic implications, J. Glaciol., 18, 101-116, 1977.

Prentice, I. C., Guiot, J., and Harrison, S. P.: Mediterranean vegetation, lake levels and palaeoclimate at the Last Glacial Maximum, Nature, 360, 658-660, 1992.

Ramrath, A., Zolitschka, B., Wulf, S., and Negendank, J. F. W.: Late Pleistocene climatic variations as recorded in two Italian maar lakes (Lago di Mezzano, Lago Grande di Monticchio), Quatern. Sci. Rev., 18, 977-992, 1999.

Ramstein, G., Kageyama, M., Guiot, J., Wu, H., Hély, C., Krinner, G., and Brewer, S.: How cold was Europe at the Last Glacial Maximum? A synthesis of the progress achieved since the first PMIP model-data comparison, Clim. Past, 3, 331-339, 2007, http://www.clim-past.net/3/331/2007/.

Sanchez, M. F. and Arquer, P. F.: New radiometric and geomorphological evidences of a last glacial maximum older than $18 \mathrm{ka}$ in SW European mountains: the example of Redes National Park (Cantabrian Mountains, NW Spain), Geodin. Acta, 15, 93-101, 2002.
Siegert, M. J. and Marsiat, I.: Numerical reconstruction of LGM climate across the Eurasian Arctic, Quatern. Sci. Rev., 20, 15951605, 2001.

Smith, J. A., Seltzer, G. O., Rodbell, D. T., and Klein, A. G.: Regional synthesis of last glacial maximum snowlines in the tropical Andes, South America, Quatern. Int., 138-139, 145-167, 2005.

Straus, L. G.: Iberia before the Iberians: the Stoneage Prehistory of Cantabrian Spain, University of New Mexico Press, Albuquerque, USA, 1992.

Svendsen, J. I., Alexanderson, H., Astakhov, V. I., Demidov, I., Dowdeswell, J. A., Funder, S., Gataullin, V., Henriksen, M., Hjort, C., Houmark-Nielsen, M., Hubberten, H. W., Ingólfson, Ó., Jakobsson, M., Kjær, K., Larsen, E., Lokrantz, H., Lunkka, J. P., Lyså, A., Mangerud, J., Matiouchkov, A., Murray, A., Möller, P., Niessen, F., Nikolskaya, O., Polyak, L., Saarnisto, M., Siegert, C., Siegert, M. J., Spielhagen, R., Stein, R.: Late Quaternary ice sheet history of northern Eurasia, Quatern. Sci. Rev., 23, 12291272. 2004.

Tarasov, P. E., Peyron, O., Guiot, J., Brewer, S., Volkova, V. S., Bezusko, L. G., Dorofeyuk, N. I., Kvavadze, E. V., Osipova, I. M., and Panova, N. K.: Last Glacial Maximum climate of the former Soviet Union and Mongolia reconstructed from pollen and plant macrofossil data, Clim. Dynam., 15, 227-240, 1999.

Tarasov, P. E., Volkova, V. S., Webb III, T., Guiot, J., Andreev, A. A., Bezusko, L. G., Bezusko, T. V., Bykova G. V, Dorofeyuk, N. I., Kvavadze, E. V., Osipova, I. M., Panova, N. K., and Sevastyanov, D. V.: Last Glacial Maximum biomes reconstructed from pollen and plant macrofossil data from northern Eurasia, J. Biogeogr., 27, 609-620, 2000.

Urdea, P.: The Pleistocene glaciation of the Romanian Carpathians, in: Quaternary Glaciations - Extent and Chronology Part I: Europe, edited by: Ehlers, J. and Gibbard, P. L., 301-308, 2004.

USGS: online available at: http://edcdaac.usgs.gov/gtopo30/ gtopo30.html, 1996, accessed 15 September 2007.

Vilaplana, J. M. and Montserrat, J.: Recent progress in Quaternary stratigraphy: the lake Llauset sequence in the Spanish Pyrenees, in: Quaternary Type Sections: Imagination or Reality?, edited by: Rose, J. and Schlüchter, C., Balkema, Rotterdam, The Netherlands, 113-124, 1989.

Woodward, J. C., Macklin, M. G., and Smith, G. R.: Pleistocene glaciation in the mountains of Greece, in: Quaternary Glaciations - Extent and Chronology Part I: Europe, edited by: Rose, J. and Schlüchter, C., 155-174, 2004.

Wu, H., Guiot, J. I., Brewer, S., and Guo, Z.: Climatic changes in Eurasia and Africa at the last glacial maximum and midHolocene: reconstruction from pollen data using inverse vegetation modelling, Clim. Dynam., 29, doi:10.1007/s00382-0070231-3, 211-229, 2007. 